Gazi University
Journal of Science
http://dergipark.gov.tr/gujs

\title{
A new natural hybrid of Verbascum L. (Scrophulariacae) from Turkey
}

\author{
Hayri DUMAN ${ }^{(0)}$, Mehmet Erkan UZUNHISARCIKLI ${ }^{\text {(D) }}$, Funda OZBEK* ${ }^{*}$ \\ University of Gazi, Faculty of Science, Department of Biology, 06500, Ankara, Turkey
}

\section{Highlights}

- Verbascum aytachii is defined as a new hybrid species to science.

- V. aytachii and its parents are compared in terms of morphology and palynology.

- The stem length, indumentum, filaments and aperture type are the most discriminative characters.

\section{Article Info}

Received: 28 Aug 2020

Accepted: 20 Jan 2021

Keywords

Endemic

Hybrid

Pollen morphology

Turkey

Verbascum

\section{Abstract}

Verbascum $\times$ aytachii nothosp. nov. H. Duman \& Uzunh. (sect. Bothrospermae) is described and illustrated as a new natural hybrid from the Orhaneli (Bursa Region) area in Western Anatolia, Turkey. This species is identified to have some intermediate morphological and palynological characteristics that place it between the parents which are $V$. ekicii and $V$. basivelatum. A comprehensive description, ecology, a distribution map and a detailed illustration are provided. Furthermore, pollen morphological properties of $V$. $\times$ aytachii and its parents are compared via light (LM) and scanning electron microscopes (SEM).

\section{INTRODUCTION}

The genus Verbascum L. (excl. Celsia L.) (Scrophulariaceae) consists of approximately 360 species in the world [1,2]. It is mainly distributed in Eurasia and N Africa with the highest diversity in Turkey where it is represented by 256 species, 131 hybrids and 6 imperfectly known or doubtful records which are divided into 13 partly artificial groups. Among them, 201 species are endemic to Turkey, this indicating an endemism ratio of about $80 \%$ [3-34].

Some similar samples of Verbascum were collected during the field investigations in Ceki village (Bursa, western Turkey) within the scope of Trans Anatolia Natural Gas Pipeline Project (TANAP). According to our experience and the literature data, the hybridization rate is very high among Verbascum species where the regions of distribution overlap in the natural area. During the field trips, we thought that some suspected specimens could be $V$. basivelatum Hub.-Mor. and V. ekicii H. Duman \& Uzunh. [35]. After thorough examinations of relevant literature and comparisons with specimens from various herbaria of Turkey and in foreign countries and also some detailed morphological and palynological investigations were carried out, the unidentified specimens were defined to be a new hybrid species, which is here named as Verbascum $\times$ aytachii $\mathrm{H}$. Duman \& Uzunh. With this new hybrid species, the number of hybrid Verbascum species in Turkey increased to 132 . 


\section{MATERIALS AND METHODS}

\subsection{Plant Materials}

At first, some flowering and fruiting specimens of Verbascum were collected by the authors during a field trip to West Anatolia (B2 Bursa-Orhaneli) in 2013. These unknown species were cross-checked regarding the descriptions of Verbascum in Huber-Morath [3, 36], Feinbrun-Dothan [37, 38], Meikle [39], Ekim [9]. Then, field explorations were carried out again in 2017 and 2018 to investigate these unusual populations of Verbascum, which could not be matched with any of the known taxa in Turkey and also seemed to have intermediate characteristics of $V$. ekicii and $V$. basivelatum. Observations were made on living plants, dried specimens, and digital images from the herbaria GAZI, ANK, HUB, ISTE, BM, G, P, K, E, WU and W (herbarium acronyms follow Thiers [40]). Authors' abbreviations of plant names were checked from Brummitt and Powell [41] and the International Plant Names Index (IPNI) [42].

\subsection{Pollen Morphological Analyses}

Pollen morphology of the investigated Verbascum species was studied by light microscopy (LM) and scanning electron microscopy (SEM). Pollen samples were prepared according to Wodehouse [43] technique for LM. Pollen grains were stained with glycerine-jelly plus safranin. Prepared pollen slides were investigated and measured under the light microscope. Measurements were performed on at least 30 pollen grains per specimen for each morphological characteristics using an Olympus CX31 Light Microscope with an ocular micrometer. For SEM studies, dried pollen grains were transferred onto stubs and then coated with gold. They were investigated and photographed with a JEOL JSM 6060 Scanning Electron Microscope. Terminology was adopted from Faegri and Iversen [44] and Punt et al. [45]. The classification of pollen shape was identified following Erdtman's system [46] based partly on the P/E ratio.

\section{RESULTS and DISCUSSION}

\subsection{Morphological Characteristics}

Verbascum $\times$ aytachii H. Duman \& Uzunh. nothosp. nov. (Figures 1-3)

(Verbascum ekicii H. Duman \& Uzunh. × Verbascum basivelatum Hub.-Mor.)

Type: TURKEY. B2 Bursa: Orhaneli, SW of Çeki village, $800 \mathrm{~m}$, 19.vii.2017, serpentine areas, M.E. Uzunhisarcıklı 2720a \& H. Duman (holotype GAZI, isotypes ANK, HUB).

Diagnosis: Verbascum $\times$ aytachii is similar to Verbascum ekicii and V. basivelatum. It is distinguished from Verbascum ekicii by its stems of length up to $100 \mathrm{~cm}$ (not to $70 \mathrm{~cm}$ ), with sparsely white lanatetomentose below, very sparsely white lanate-tomentose to glabrous above (not densely white lanatetomentose), pedicels filiform, glabrous to sparsely tomentose (not pedicels thick, densely tomentose), densely pellucid-punctate outside (not without pellucid glands), all filaments with densely purple-violet hairs, two anterior glabrous near apex (not two filaments with purple-violate hairs, others white-yellowish, two anterior glabrous near apex). It can be distinguished from $V$. basivelatum by its stems up to $100 \mathrm{~cm}$ (not to $150 \mathrm{~cm}$ ), fertile stamens 5 (not fertile stamens 4 , without or rarely with an antherless $5^{\text {th }}$ staminode), all filaments with densely purple-violet, rarely white-purplish hairs, two anterior glabrous near apex (not all filaments white-yellowish hairs, two anterior glabrous near apex), (Table 1). 
Table 1. Morphological comparison between Verbascum x aytachii, V. ekicii and V. basivelatum

\begin{tabular}{|c|c|c|c|}
\hline Characters & V.x aytachii & V.ekicii & V. basivelatum \\
\hline Stem (cm) & up to 100 & up to 70 & up to 150 \\
\hline Situation of hairy & $\begin{array}{l}\text { with sparsely white lanate- } \\
\text { tomentose below, very sparsely } \\
\text { white lanate-tomentose to } \\
\text { glabrous above }\end{array}$ & densely white lanate-tomentose & $\begin{array}{l}\text { densely or very densely lanate, } \\
\text { glabrous or sparsely glandular } \\
\text { above }\end{array}$ \\
\hline Pedicel & $\begin{array}{l}\text { filiform, glabrous to sparsely } \\
\text { tomentose }\end{array}$ & thick, densely tomentose & filiform, glabrous \\
\hline Corolla & densely pellucid-punctate outside & without pellucid glands & densely pellucid-punctate outside \\
\hline Stamen (fertile) & $\begin{array}{l}5 \text {; all filaments with densely } \\
\text { purple-violet hairs, two anterior } \\
\text { glabrous near apex }\end{array}$ & $\begin{array}{l}5 \text {; two filaments with purple- } \\
\text { violate hairs, others white- } \\
\text { yellowish, two anterior glabrous } \\
\text { near apex }\end{array}$ & $\begin{array}{l}4 \text {; two anterior ones glabrous, } 3 \\
\text { posterior ones very densely } \\
\text { villous-velutinous and with long } \\
\text { white papillae }\end{array}$ \\
\hline
\end{tabular}

Description: Biennial to perennial herb, with sparsely white lanate-tomentose below, very sparsely white lanate-tomentose to glabrous above. Stem terete, erect, $50-100 \mathrm{~cm}$, branched above. Basal leaves with petiole 1.5-4 cm, lamina 3.5-7.5 × 1.5-2.5 cm, elliptic to oblanceolate, crenate-denticulate, obtuse to acute. Cauline leaves small, very few, sessile, $0.7-4 \times 0.3-1.5 \mathrm{~cm}$, oblong- elliptic, entire to crenulate, obtuseacuminate. Inflorescence lax raceme, slender, flowers in distant clusters of 1-4; axis completely glabrous to very sparsely tomentose. Bracts minute, scale-like, lanceolate-linear. Bracteoles absent. Pedicels filiform, 3-6 mm, glabrous to sparsely tomentose. Calyx $1.8-2 \mathrm{~mm}$, divided almost to base, lobes linear to oblanceolate, obtuse, sparsely branched tomentose. Corolla rotate, c. $12 \mathrm{~mm}$ diam., yellow, densely pellucid-punctate outside, papillose-villosulous at base of upper lobes within, glabrous outside. Stamens 5; anthers reniform; all filaments with densely purple-violet, rarely white-purplish hairs, two anterior glabrous near apex. Ovary subglobose; stylus 6-9 mm, filiform; stigma spathulate.

Phenology: Flowering time from June to July.

Habitat and ecology of $\boldsymbol{V} . \times$ aytachii: The new hybrid species grows in serpentine areas under the Pinus brutia Ten. forest in company with Phillyrea latifolia L., Juniperus oxycedrus L., Cistus creticus L., Quercus infectoria G. Olivier, Dianthus goekayi Kaynak, Yılmaz \& Taşkın, Saponaria pamphylica Boiss. \& Heldr., Dactylis glomerata L., Allium flavum L. subsp. tauricum (Besser ex Reichb.) Stearn and Alyssum dudleyi N. Adiguzel \& R.D. Reeves.

Etymology: The new hybrid species is named in honour of Prof. Dr. Zeki Aytaç.

\section{Specimens examined}

Verbascum ekicii. -TURKEY. B2 Bursa: Orhaneli, SW of Çeki village, 800 m, 19 July 2017, serpentine areas, M.E. Uzunhisarcıkl 2720 \& H. Duman (holotype GAZI!, isotypes ANK!, HUB!); ibid., 19 May 2013, M. Ekici 4473 (GAZI!).

Verbascum basivelatum. -TURKEY. A2 Bursa: Bursa-Keles, 37 km W Keles, 510 m, 08 July 1982, Max Nydegger 17028 (GAZI!). A2 Bursa: $1 \mathrm{~km}$ from Soğukpınar to Uludağ, $1100 \mathrm{~m}$, 05 July 1980, Max Nydegger 15135 (GAZI!). A2 Bursa: Harmanc1k-Orhaneli, 4 km N Harmanc1k, 770 m, 05 August 1983, Max Nydegger 18639 (GAZI!). B3 Eskişehir: Porsuk dam - Türkmen mountain, 930 m, rocky and disturbed forest, 23 July 1993, Z. Aytaç 6208 (GAZI!). B3 Eskişehir: around Porsuk dam, 992 m, serpentine, 18 July 2002, FAK 3385 (GAZI!). 

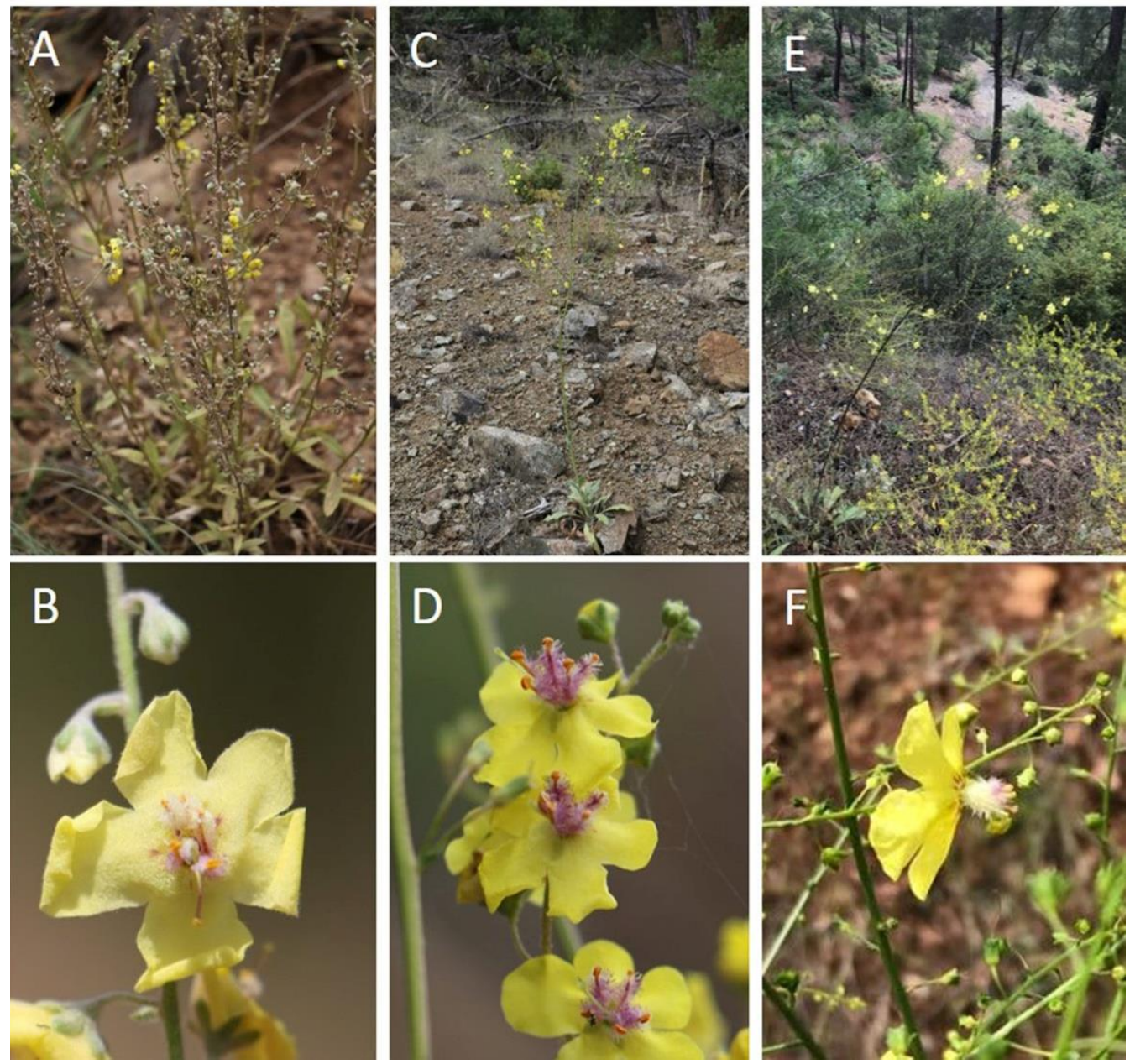

Figure 1. Habitus and flowers of V. ekicii $(A, B), V . \times$ aytachii $(C, D)$ and V. basivelatum $(E, F)$ 




Figure 2. V. $\times$ aytachii H. Duman \& Uzunh. A1) Stem and basal leaves, A2) Stem and inflorescence, B) Cluster of flowers, C1-C2) Stamens, D) Situation of hairy, E) Surface of petal 


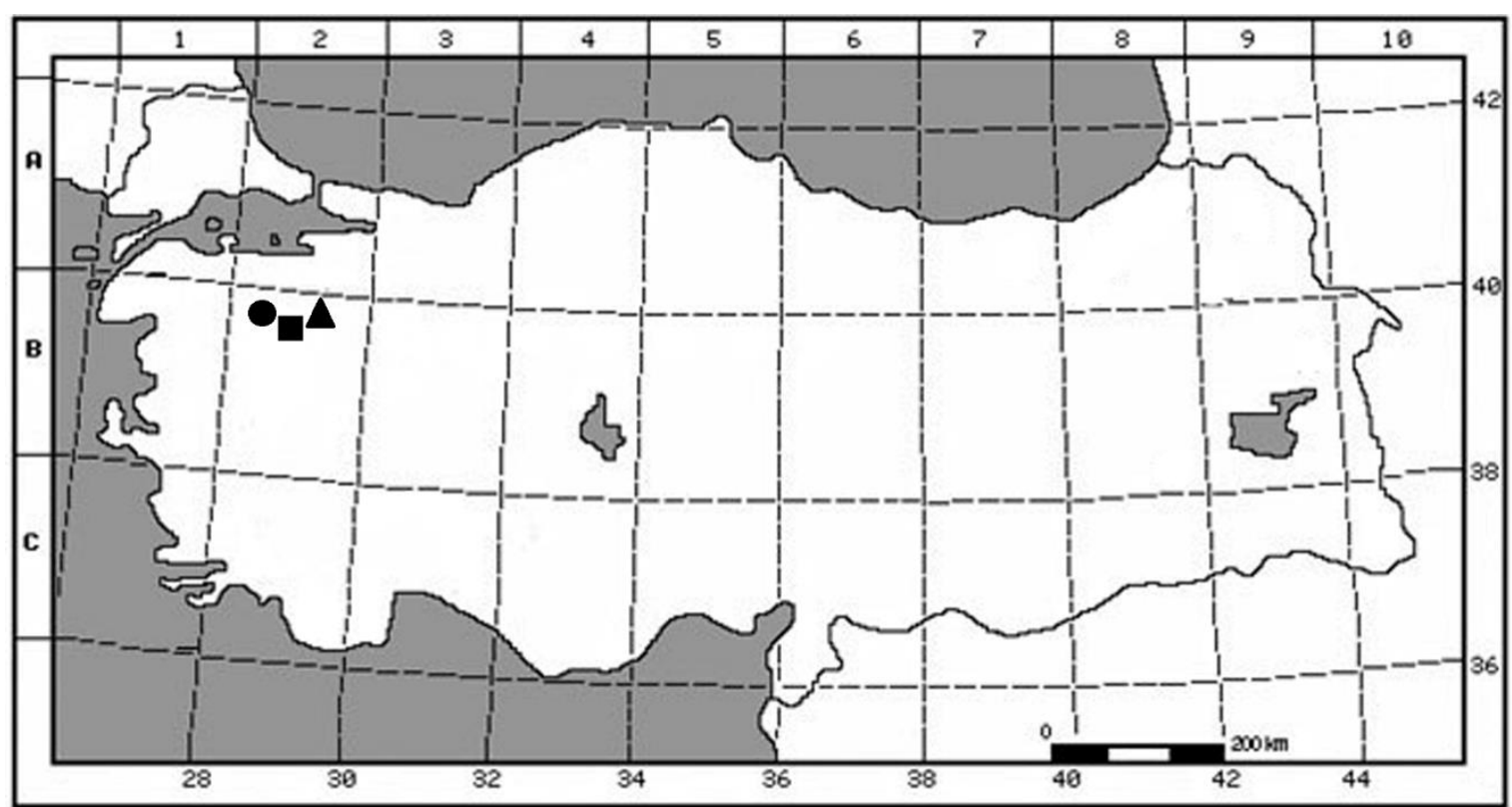

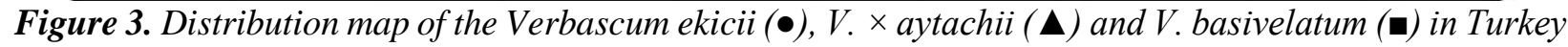

\subsection{Pollen Morphological Characteristics}

The pollen grains of $V . \times$ aytachii, $V$. ekicii and $V$. basivelatum are isopolar and radially symmetrical. The aperture type is generally trizonocolporate in V. ekicii and V. basivelatum; but 5\% tetracolporate, $3 \%$ trisyncolporate and $92 \%$ trizonocolporate pollen grains have been detected in $V . \times$ aytachii. The pollen shape is oblate-spheroidal in $V . \times$ aytachii $(\mathrm{P} / \mathrm{E}: 0.94 \pm 0.02)$, V. ekicii $(\mathrm{P} / \mathrm{E}: 0.96 \pm 0.02)$ and $V$. basivelatum $(\mathrm{P} / \mathrm{E}: 0.98 \pm 0.02)$. The exine ornamentation is microreticulate at polar and equatorial regions in these investigated Verbascum species (Table 2, Figure 4).

Table 2. Pollen morphological features of $V . \times$ aytachii and its parents

\begin{tabular}{|c|c|c|c|c|c|c|c|c|c|}
\hline \multirow[t]{2}{*}{ Species } & \multicolumn{3}{|c|}{$\mathbf{P}(\mu \mathrm{m})$} & \multicolumn{3}{|c|}{$E(\mu \mathrm{m})$} & \multirow[t]{2}{*}{$\mathbf{P} / \mathbf{E}$} & \multirow[t]{2}{*}{ Aperture Type } & \multirow[t]{2}{*}{ Ornamentation } \\
\hline & Min. & Max. & Mean & Min. & Max. & Mean & & & \\
\hline V. $\times$ aytachii & 19 & 25 & $21.53 \pm 1.38$ & 20 & 29 & $22.93 \pm 1.93$ & $0.94 \pm 0.02$ & $\begin{array}{l}5 \% \text { tetracolporate, } 3 \% \\
\text { trisyncolporate, } 92 \% \\
\text { trizonocolporate }\end{array}$ & Microreticulate \\
\hline V. ekicii & 21 & 23.5 & $22.1 \pm 0.52$ & 20 & 24.75 & $22.9 \pm 1.07$ & $0.96 \pm 0.02$ & Trizonocolporate & Microreticulate \\
\hline V. basivelatum & 18.5 & 22.5 & $20.44 \pm 0.95$ & 19 & 22 & $20.69 \pm 0.74$ & $0.98 \pm 0.02$ & Trizonocolporate & Microreticulate \\
\hline
\end{tabular}



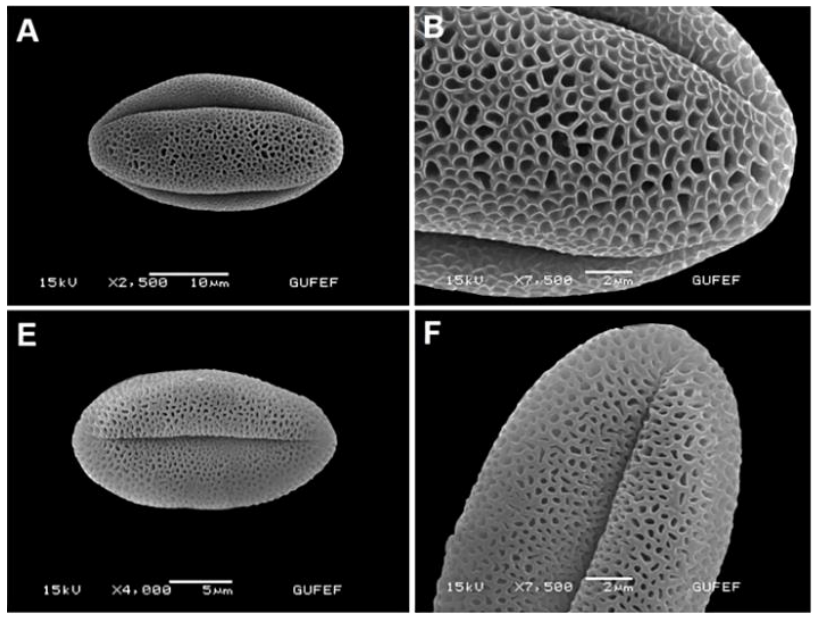

Figure 4. SEM micrographs basivelatum, $E-H) V$. × aytachii, $A, C, E)$ Ge
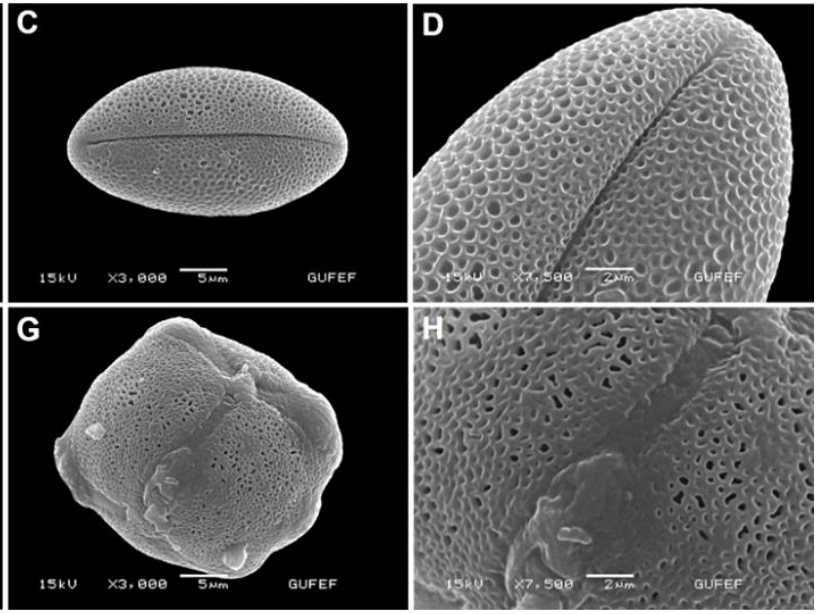

stigated Verbascum species. A, B) V. ekicii, $C, D) V$. ornamentation

Verbascum $\times$ aytachii is similar to its parents, V. ekicii and $V$. basivelatum. It is differentiated from Verbascum ekicii due to important characters such as densely pellucid-punctate outside, all filaments with densely purple-violet hairs and two anterior glabrous near apex. Also, it can be distinguished from $V$. basivelatum by some characteristics, such as fertile stamens 5 , all filaments with densely purple-violet, rarely white-purplish hairs and two anterior glabrous near apex.

The pollen morphologies of $V$. $\times$ aytachii and its parents were compared and some differences were found in terms of these characteristics. Al-Hadeety et al. [47] observed the variations in pollen shape of 20 species of Verbascum from Iran. They divided the Verbascum species they investigated into four groups according to the pollen shape: prolate-spheroidal, prolate, subprolate and also oblate-spheroidal. Contrary to these researchers, we observed only oblate-spheroidal pollen shape in our studied Verbascum species. Öztürk et al. [48] determined that trisyncolpate and trizonocolpate aperture type as well as trizonocolporate in their studied Verbascum species distributed in Turkey. They reported that aperture type was a diagnostic character for taxonomic discrimination between and within the groups in the genus Verbascum. The aperture type of our studied species is generally trizonocolporate, whereas in $V . \times$ aytachii they are $5 \%$ tetracolporate, $3 \%$ trisyncolporate and $92 \%$ trizonocolporate. Therefore, the aperture type is an important character that can be used to distinguish these species from the other morphological features.

As a result of this study, the number of hybrid species belonging to the genus Verbascum in Turkey has increased to 132 .

\section{ACKNOWLEDGEMENTS}

The authors thank to the curators of GAZI, ANK, HUB, BM, G, P, K, E, WU and W Herbaria, who allowed us to study their Verbascum material. In addition, we are grateful to TANAP Natural Gas Transmission Company and ÇINAR Engineering Consulting Inc. for financial support and Fatma Şen for the illustrations.

\section{CONFLICTS OF INTEREST}

No conflict of interest was declared by the authors. 


\section{REFERENCES}

[1] Heywood, V. H., Flowering Plants of the World, Oxford University Press, Oxford, 335, (1993).

[2] Mabberley, D. J., Mabberley's plant-book, 3rd edition. Cambridge University Press, Cambridge, XVIII + 1021, (2008).

[3] Huber-Morath, A., Verbascum L., In: Davis, P.H. (ed.), Flora of Turkey and the East Aegean Islands, vol. 6, Edinburgh University Press, Edinburgh, 461-603, (1978).

[4] Al-Bermani, A. K. A. and Al-Musawi, A. H. E., "Seven new hybrids of Verbascum from Iraq", Agris, 5(1): 39-50, (1987).

[5] Davis, P. H., Mill, R. R., Tan, K., Flora of Turkey and the East Aegean Islands, vol. 10, Edinburgh University Press, Edinburgh, 590, (1988).

[6] Belyanina, M. B., Kiseleva, K.V., "Hybrid of Verbascum phlomoides L. and V. pinnatifidum Vahl from the Crimea", Byulleten' Glavnogo Botanicheskogo Sada, 158: 41-45, (1990).

[7] Vural, M., Aydoğdu, M., "A new species from central Anatolia Verbascum gypsicola (Scrophulariaceae)", The Karaca Arboretum Magazine, 2(2): 75-78, (1993).

[8] Sutory, K., "Two hybrids of Verbascum (Scrophulariaceae) from Rumania”, Bocconea, 5: 643-646, (1997).

[9] Ekim, T., Verbascum L., In: Güner, A., Ozhatay, N., Ekim, T., Başer, K. H. C. (eds.), Flora of Turkey and the East Aegean Islands (Suppl. 2), vol. 11, Edinburgh University Press, Edinburgh, 193, (2000).

[10] Sutory, K., "Two new hybrids of Verbascum from Turkey and Spain", Bocconea, 13: 457-460, (2001a).

[11] Sutory, K., "Verbascum $\times$ sibyllinum, a new nothospecies from Italy", Willdenowia, 31: 315-318, (2001b).

[12] Karavelioğulları, F. A., Duran, A., Hamzaoğlu, E., "Verbascum tuna-ekimii (Scrophulariaceae) a new species from Turkey", Annales Botanici Fennici, 41: 227-231, (2004).

[13] Sutory, K., "New hybrids of Verbascum (Scrophulariaceae) from Turkey", Turkish Journal of Botany, 28: 261-262, (2004).

[14] Karavelioğulları, F. A., Vural, M., Polat, H., “Two new taxa from Central Anatolia Turkey”, Israel Journal of Plant Sciences, 54: 105-111, (2006).

[15] Kaynak, G., Daşkın, R., Yılmaz, O., Erdoğan, E., "Verbascum yurtkurianum (Scrophulariaceae) a new species from north west Anatolia, Turkey", Annales Botanici Fennici, 43: 456-459, (2006).

[16] Özhatay, N., "Check-list of additional taxa to the Supplement Flora of Turkey III", Turkish Journal of Botany, 30: 281-316, (2006).

[17] Parolly, G., Tan, K., "Verbascum lindae (Scrophulariaceae), a new species from SW Anatolia", Willdenowia, 37: 277-282, (2007).

[18] Karavelioğulları, F. A., Aytaç, Z., "Revision of the genus Verbascum L. (Group A) in Turkey", Botany Research Journal, 1: 9-32, (2008). 
[19] Karavelioğulları, F. A., Uzunhisarcıkl1, M. E., Çelik, S., "Verbascum ozturkii (Scrophulariaceae), a new species from East Anatolia, Turkey”, Pakistan Journal of Botany, 40: 1595-1599, (2008).

[20] Parolly, G., Eren, Ö., "Verbascum haraldi-adnani (Scrophulariaceae), a new chasmophytic species from SW Anatolia, Turkey”, Willdenowia, 38: 127-134, (2008).

[21] Dane, F., Y1lmaz, G., "A new natural hybrid of Verbascum (Scrophulariaceae) from European Turkey”, Phytologia Balcanica, 15(2): 181-184, (2009).

[22] Karavelioğulları, F.A., "A new record Verbascum szovitsianum Boiss. var. szovitsianum (Scrophulariaceae) from Turkey”, Biodicon, 2: 68-70, (2009).

[23] Karavelioğulları, F.A., Ocak, A., Ekici, M., Cabi, E., "Verbascum eskisehirensis sp. nov. (Scrophulariaceae) from central Anatolia, Turkey", Nordic Journal of Botany, 27: 222-227, (2009).

[24] Bani, B., Adıgüzel, N., Karavelioğulları, F.A., "A new species (Verbascum turcicum sp. nov., Scrophulariaceae) from South Anatolia, Turkey", Annales Botanici Fennici, 47: 489-492, (2010).

[25] Karavelioğulları, F. A., Çelik, S., Başer, B., Yavru, A., "Verbascum ergin-hamzaoglui (Scrophulariaceae), a new species from South Anatolia, Turkey", Turkish Journal of Botany, 35: 275-283, (2011).

[26] Karavelioğulları, F. A., Verbascum L., In: Güner, A., Aslan, S., Ekim., T., Vural, M., Babaç, M. T. (eds.), Türkiye Bitkileri Listesi (Damarlı Bitkiler), Nezahat Gökyiğit Botanik Bahçesi ve Flora Araştırmaları Derneği Yayını, İstanbul, 850-870, (2012).

[27] Karavelioğulları, F. A., Vural, M., Şahin, B., Aslan, S., "İç Anadolu Bölgesi’nden (Türkiye) yeni bir tür: Verbascum aydogdui (Scrophulariaceae)”, Bağbahçe Bilim Dergisi, 1: 63-71, (2014a).

[28] Karavelioğulları, F. A., Yüce, E., Başer, B., "Verbascum duzgunbabadagensis (Scrophulariaceae), a new species from eastern Anatolia, Turkey”, Phytotaxa, 181(1): 47-53, (2014b).

[29] Fırat, M., "Verbascum kurdistanicum (Scrophulariaceae), a new species from Hakkâri, Turkey", PhytoKeys, 52: 89-94, (2015).

[30] Karavelioğulları, F. A., "Verbascum ibrahim-belenlii (Scrophulariaceae), a new species from East Anatolia, Turkey”, Phytotaxa, 212(3): 246-248, (2015a).

[31] Karavelioğulları, F. A., "Verbascum misirdalianum (Scrophulariaceae), a new species from central Anatolia, Turkey”, Phytotaxa, 217(1): 96-99, (2015b).

[32] Çıngay, B., Karavelioğulları, F. A., "A new species of Verbascum, V. nihatgoekyigitii (Scrophulariaceae), from southeastern Anatolia, Turkey", Phytotaxa, 269: 287-293, (2016).

[33] Duman, H., Uzunhisarcıkl, M. E., Tan, K., "Verbascum mughlaeum (Scrophulariaceae), a new species from SW Anatolia, Turkey”, Phytotaxa, 291(3): 231-236, (2017).

[34] Sutory, K., "Typifications of Verbascum adrianopolitanum and V. banaticum, and a new hybrid name Verbascum × stribrnyi (Scrophulariaceae)", Annales Botanici Fennici, 54: 125-129, (2017).

[35] Duman, H., Uzunhisarcıkl, M. E., Özbek, F., “A new species Verbascum (Scrophulariaceae) from western Turkey”, Botany Letters, 167(4): 409-416, (2020).

[36] Huber-Morath, A., Verbascum L., In: Rechinger, K.H. (ed.), Flora Iranica 147, Akademische Drucku-Verlagsanstalt, Graz, 1-51, (1981). 
[37] Feinbrun-Dothan, N., Verbascum L., In: Zohary, M. and Feinbrun-Dothan, N. (eds.), Flora Palaestina (Text) 3, Academic Press, Jerusalem, 282-302, (1978a).

[38] Feinbrun-Dothan, N., Verbascum L., In: Zohary, M. and Feinbrun-Dothan, N. (eds.), Flora Palaestina (Plates) 3, Academic Press, Jerusalem, 170-182, (1978b).

[39] Meikle, R. D., Verbascum L., In: Meikle, R. D. (ed.), Flora of Cyprus 2, Royal Botanic Gardens, Kew, 1196-1200, (1985).

[40] Thiers, B., "Index herbariorum: A global directory of public herbaria and associated staff", http://sweetgum.nybg.org/ih/. Access date: 15.08.2020.

[41] Brummitt, R. K., Powell, C. E., Authors of Plant Names, Royal Botanic Gardens, Kew, 732, (1992).

[42] IPNI, "The International Plant Names Index", http://www.ipni.org/ipni/authorsearchpage.do, (2019). Access date: 16.08.2020.

[43] Wodehouse, R. P., Pollen Grains, Mc Graw-Hill, New York, London, 543, (1935).

[44] Faegri, K., Iversen, J., Textbook of Pollen Analysis, 4th edition, Wiley, New York, 328, (1992).

[45] Punt, W., Hoen, P.P., Blackmore, S., Nilsson, S., Le Thomas, A., "Glossary of Pollen and Spore Terminology", Review of Palaeobotany and Palynology, 143: 1-81, (2007).

[46] Erdtman, G., Handbook of Palynology, Morphology, Taxonomy and Ecology, Munksgaard, Copenhagen, 486, (1969).

[47] Al-Hadeethy, M., Al-Mashhadani, A., Al-Khesraji, T., Barusrux, S., Al-Jewari, H., Theerakulpisut, P. and Pornpongrungrueng, P., "Pollen morphology of Verbascum L. (Scrophulariaceae) in Northern and Central Iraq", Bangladesh Journal of Plant Taxonomy, 21: 159-165, (2014).

[48] Öztürk, A., Güney, K.B., Bani, B., Güney, K., Karavelioğulları, F.A., Pınar, N.M., Çeter, T., "Pollen morphology of some Verbascum (Scrophulariaceae) taxa in Turkey", Phytotaxa, 333(2): 209-218, (2018). 